\title{
Predation intensity in estuarine soft bottoms: between-habitat comparisons and experimental artifacts
}

\author{
Fiorenza Micheli* \\ University of North Carolina at Chapel Hill, Institute of Marine Sciences, Morehead City, North Carolina 28557, USA
}

\begin{abstract}
The aim of this study was to determine whether experimental artifacts have the potential to bias comparisons of relative predation intensity among different soft-sediment estuarine habitats. A field experiment was used to test (1) whether predation intensity on the infaunal clam Mercenarza mercenaria (L.) differed between shallow-subtidal and intertidal sand flats, (2) whether predation on clams differed between intertidal sand flats and vegetated habitats [the edge of Spartina alterniflora (Loisel) salt marshes] of similar elevation, and (3) whether the outcome of these comparisons was influenced by the experimental method used. For mobile prey, some restraint on prey movement is typically required to compare predation intensity among different habitats. This is most often achieved by tethering prey. Tethering and other experimental interventions may induce different experimental artifacts in estimates of predation intensity in different habitats, which would invalidate between-habitat comparisons (Peterson \& Black 1994: Mar Ecol Prog Ser 111:289-297). l used combinations of 2 types of prey restraint, tethers and buried fences, to test for possible interactive effects of habitat and prey restraint on prey mortality. Tethered or untethered clams were deployed within fenced or unfenced field plots within each habitat type, in a factorial design, and were exposed to the natural assemblage of predators for $1 \mathrm{wk}$. Within each habitat type, both tethering and fencing increased the proportion of clams recovered live after 1 wk compared to the treatment in which no prey restraints were used. Significantly more live clams were recovered in the intertidal sand flats than in the subtidal sand bottoms within field plots enclosed with buried fences, suggesting lower predation intensity in the intertidal than in subtidal sand flats. In contrast, there was no significant difference in proportions of live clams between subtidal sand bottoms and intertidal sand flats within unfenced plots. These results were obtained with both tethered and untethered clams. Significantly more clams were recovered live in intertidal sand flats than in intertidal salt marshes of similar elevation in all treatment combinations, suggesting lower predation intensity in unvegetated than in vegetated habitats. This result was unexpected because habitat structural complexity is known to decrease predation rates in other shallow marine habitats, such as rocky intertidal habitats and seagrass beds. Results of this field experiment indicate that prey restraints can bias not only estimates of predation intensity within a single habitat type but can also bias between-habitat comparisons of predation intensity, probably by causing experimental artifacts of different magnitudes in each habitat. The actual magnitude of experimental artifacts in each habitat type can only be estimated with direct observations of predator-prey interactions in the field.
\end{abstract}

KEY WORDS: Bivalves Clams - Experimental artifacts - Fencing - Intertidal Mercenaria mercenaria Predation Marine soft bottoms Tethering

\section{INTRODUCTION}

Predation has important effects on the structure and persistence of prey communities, particularly in the marine environment (Sih et al. 1985). The effects of

·E-mail: fmicheli@email.unc.edu abiotic and biotic factors on rates of predation on benthic invertebrates have been studied extensively in shallow subtidal and intertidal marine systems (Paine 1966, Dayton 1971, Connell 1972, 1975, Menge 1978a, b, 1983, Underwood \& Denley 1984, Wilson 1990, Peterson 1991, Wootton 1993). One generalization of earlier studies conducted on temperate rocky shores is 
that the intensity of predation on benthic organisms tends to decline with increasing elevation on shore, due to the reduced feeding time available to marine predators higher in the intertidal (Dayton 1971, Connell 1972, 1975, Menge 1978a, b, 1983; but see Underwood \& Denley 1984, Peterson 1991). A second generalization derived from experimental studies of intertidal and shallow marine habitats is that predation intensity on benthic and epibenthic animals decreases with increasing structural complexity of the habitat (Heck \& Thoman 1981, Menge \& Lubchenco 1981, Peterson 1982a, Summerson \& Peterson 1984). Crevices on rocky shores (Menge \& Lubchenco 1981) and vegetation in soft bottoms (Coen et al. 1981, Peterson 1982a, Summerson \& Peterson 1984, Leber 1985. Reise 1985) can provide refuges from predation for benthic prey

For mobile or unattached prey, experiments comparing predation intensity among different tidal elevations or habitat types must distinguish prey losses due to predation from prey losses due to emigration or passive transport by currents and waves. This can be achieved by restraining prey movements with enclosures, such as buried fences (Commito 1982, Peterson 1982a, b, Ambrose 1984, Irlandi \& Peterson 1991, Peterson \& Black 1993), or with tethers (Barbeau \& Scheibling 1994, Peterson \& Black 1994, Zimmer-Faust et al. 1994, Aronson \& Heck 1995). Tethers have been shown to induce artifacts in estimates of predation rates on juvenile blue crabs and scallops by interfering with their escape responses, thereby increasing their susceptibility to predators (Barbeau \& Scheibling 1994, Zimmer-Faust et al. 1994)

The implicit assumption made to justify the use of tethering and of experimental manipulations in general is that experimental artifacts bias estimates of predation rates identically across habitats, thereby allowing comparisons of relative predation intensity to be conducted. Peterson \& Black (1994) challenged this assumption by arguing that artifacts induced by restraining prey movements may vary with experimental treatment, thereby confounding comparisons between treatments. Different magnitudes and/or direction of artifacts among experimental treatments can represent a serious obstacle to the interpretation of ecological field experiments (Peterson \& Black 1994; but see Aronson \& Heck 1995 for a critique). For example, the effects of restraint on escape response of prey may vary depending on the prey species and size. Tethering and fencing may also have different effects on the foraging efficiency of various predators. Since the species composition and size structure of predator guilds often varies with habitat type, the effects of tethering and fencing on estimates of predation rates could vary among habitats.
Tethering and fencing may also affect the same predator differently depending on external conditions such as sediment type, structural complexity of the habitat, risk of predation by higher-order predators, and duration of time when intertidal habitats are submerged. Each of these variables is likely to modify a predator's behavior (Arnold 1984, Kneib 1984, Lipcius \& Hines 1986, Lima \& Dill 1990, Micheli 1996) and thus may modify the effects of tethers or fences on its foraging rates.

One approach to investigating interactions between artifacts of experimental manipulations and treatment level is to vary the frequency, the intensity, or the type of intervention at each treatment level as a means of estimating the artifacts indirectly (Peterson \& Black 1994). In particular, if different experimental manipulations yield different conclusions, one can conclude that experimental artifacts interact with the experimental treatment and that turther investigation of the mechanisms producing artifacts is needed.

I conducted a field experiment to test (1) whether survivorship of juvenile hard clams Mercenaria mercenaria is greater in intertidal than in shallow-subtidal sand flats, (2) whether survivorship of juvenile hard clams is greater in vegetated than in unvegetated intertidal habitats of similar tidal elevation, and (3) whether the outcome of these comparisons is influenced by the experimental method used.

\section{METHODS}

Field experiments were conducted at 2 sites, located approximately $1 \mathrm{~km}$ apart, on the northwestern (Site 1) and southern (Site 2) sides of a group of salt marsh islands called Middle Marsh, in Back Sound, North Carolina, USA (see Peterson \& Beal 1989 for a description of the study area). At each site, identical experimental plots were set up in 3 habitats: (1) a shallowsubtidal sand bottom, (2) an intertidal sand flat, and (3) the edge of a Spartina alterniflora intertidal salt marsh. Water depths in the subtidal sand-bottom habitat were approximately 10 to $15 \mathrm{~cm}$ at spring low tides, and reached 1.0 to $1.5 \mathrm{~m}$ at high tides. The intertidalflat and marsh habitats were at similar tidal elevations, both approximately $40 \mathrm{~cm}$ higher than the subtidal habitat. These habitats were chosen to separate the effects of tidal elevation (by comparing subtidal sand bottoms and intertidal sand flats) and of the presence/absence of vegetation (by comparing intertidal flats and marsh edges while holding elevation constant) on survivorship of juvenile hard clams.

Characteristics of the top $5 \mathrm{~cm}$ of sediments were determined by dry sieving (Folk 1980) 3 replicate 5 $\mathrm{cm}$ diameter cores from each habitat (Table 1). Plant 
Table 1. Sediment characteristics in the 3 habitat types. Fine sands $(2.0$ to $4.0 \phi$ units) were the dominant size fraction in all habitats. Average percentages (by weight) of 3 replicate samples are reported. Values in parentheses represent $1 \mathrm{SE}$

\begin{tabular}{|c|c|c|c|c|c|c|}
\hline \multirow{2}{*}{ Sediment } & \multicolumn{2}{|c|}{ Subtudal sand bottom } & \multicolumn{2}{|c|}{ Intertidal sand flat } & \multicolumn{2}{|c|}{ Intertidal salt marsh } \\
\hline & Site 1 & Site 2 & Site 1 & Site 2 & Site 1 & Site 2 \\
\hline$\%$ silt-clay & $0.5(0.1)$ & $1.1(0.1)$ & $0.1(0.04)$ & $0.5(0.1)$ & $11.6(2.5)$ & $6.7(0.3)$ \\
\hline$\%$ fine sands & $80.3(5.2)$ & $93.2(1.7)$ & $94.2(0.8)$ & $87.9(1.1)$ & $84.3(2.5)$ & $89.0(1.2)$ \\
\hline
\end{tabular}

densities were determined by counting Spartina shoots within 5 replicate $0.5 \mathrm{~m}^{2}$ quadrats haphazardly tossed just inside of the marsh edges (approx. $1 \mathrm{~m}$ from the vegetation edge). Plant densities ( \pm SE) were $70.0 \pm 12.5$ and $72.8 \pm 8.4$ shoots $\mathrm{m}^{-2}$ at Sites 1 and 2 , respectively.

Hard clams Mercenaria mercenaria were chosen as prey for the following reasons: (1) they can be easily marked and tethered without apparent damage to the organism; (2) the cause of their mortality can be inferred from examination of their shells (see below); and (3) they naturally occur in the habitats compared in this study. Average densities of hard clams in the study area are generally low: 0.4 to $1.6 \mathrm{~m}^{-2}$ in sand flats, 9 to $11.3 \mathrm{~m}^{-2}$ in seagrass beds (Peterson $1982 \mathrm{~b}$, Peterson et al. 1984), and $3.5 \mathrm{~m}^{-2}$ along the marsh edges (F. Micheli unpubl. data), but higher densities, closer to those used in this experiment $\left(20 \mathrm{~m}^{-2}\right)$, have been reported elsewhere 10.9 to $18.4 \mathrm{~m}^{-2}$ in the Long Island Sound, NY, USA area; MacKenzie 1977). Juvenile hard clams ranging from 15 to $25 \mathrm{~mm}$ in length (mean \pm SE $19.6 \pm 0.28 \mathrm{~mm}$, based on a subsample of 50 animals) were obtained from a local aquaculture facility (ARC Inc., Atlantic, NC, USA). Clams were marked on each valve with acrylic paint (Mark-Tex Corp., Englewood, NJ, USA.) to distinguish them from pre-existing clams. Half of the clams were tethered to metal gardening staples with $15 \mathrm{~cm}$ long pieces of a clear monofilament line $(10 \mathrm{lb}$ test $\approx 4.5 \mathrm{~kg})$, while the remaining half remained untethered. Tethering involved placing a monofilament line over the shell, covering it with a drop of cyanoacrylate glue and attaching a small piece of electrical tape over the line and glue. Tethered and untethered clams were held in containers in flowing sea water and were handled similarly until deployment in the field. plots

Fencing consisted of enclosing plots with a $2.9 \mathrm{~m}$ long and $15 \mathrm{~cm}$ high strip of $6 \mathrm{~mm}$ polyethylene Vexar mesh (Internet Inc., Minneapolis, MN, USA), folded into a square and reinforced at the corners by steel rods. These fences were buried to surround the plots, with the top edges of walls flush with the sediment surface. Buried fences proved effective in constraining clam migration out of experimental plots in previous studies (Peterson 1982a, b, Peterson \& Beal 1989, Irlandi \& Peterson 1991).
Either tethered or untethered clams were deployed in fenced and unfenced $0.5 \mathrm{~m}^{2}$ plots, in an orthogonal balanced design yielding the following treatments: (1) tethered clams in fenced plots; (2) untethered clams in fenced plots; (3) tethered clams in unfenced plots; (4) untethered clams in unfenced plots. Each treatment was replicated 5 times within each habitat, at both sites.

Ten clams were placed haphazardly in each plot. Clams were pushed under the sediment surface, in living position. Prey naturally found in the plots were not removed prior to addition of experimental clams to avoid disrupting plant roots and other structures that may provide refuges from predation for the clams, particularly within the salt marsh habitat. Therefore total prey density in the experimental plots was likely to differ among the 3 habitat types. The experiment began 11 May 1992. After $1 \mathrm{wk}$, all surviving clams and clam shells were collected from plots by digging around the tethers, and then using fingers to plow the sediments in the entire plot to a depth of approximately $10 \mathrm{~cm}$. Because hard clams are shallow-burrowers, this depth was deemed sufficient to retrieve experimental clams (Peterson 1982a). A short duration was chosen for this experiment because a pilot study conducted in the study area had indicated that a substantial number of clams were lost to predators within the first week (F. Micheli unpubl. data). Clams were assigned to 1 of 5 categories: (1) alive; (2) dead with undamaged shells, presumably killed by starvation, physical stress, disease, or parasitism (Peterson 1982b); (3) dead with shells either crushed or chipped along the edges; (4) dead with valves either filed at the edge or drilled; and (5) missing

Clams with either crushed or chipped valves had been killed by crabs (mainly the blue crab Callinectes sapidus Rathbun, the stone crab Menippe mercenaria Say, and the mud crab Panopeus herbstii H. Milne Edwards), clams with valves filed at the edges had been killed by whelks Busycon spp., and clams with drilled valves had been killed by moon snails [mainly Polinices duplicatus (Say)] (Peterson 1982a) These predators were potentially able to consume clams in the size range used in this experiment $(15$ to $25 \mathrm{~mm}$ in length; Whetstone \& Eversole 1981, Peterson 1982a, 
1990, Arnold 1984, F. Micheli pers. obs.). Missing clams could have been carried away by predators, actively emigrated from the plots, passively transported either alive or after death of any sort by waves and currents, or lost due to sampling error. Sampling error was assumed to be small: Peterson (1982a) reported recoveries of 96 to $99 \%$ for hard clams sampled with a similar technique. Consequently, in the treatment where neither tethers nor fences were used, the category of missing clams includes predation, active migration, and passive transport. In the treatment where only fences were used, the missing clam category includes both predation and possibly passive transport, and in the treatments where clams were tethered it includes only predation.

Percentages of live, dead-undamaged, dead with crushed or chipped shells, dead with drilled or filed shells, and missing clams were analyzed separately with fixed-factor 4-way ANOVAs, with site (Sites 1 and 2), habitat type (sand bottom, intertidal sand flat, and salt marsh edge), fencing (fenced and unfenced plots) and tethering (tethered and untethered clams) treatments as the fixed factors. Whether site should be considered a fixed or a random factor in ANOVA models is often unclear (Bennington \& Thayne 1994). In this study, I chose to consider site as a fixed factor because field sites were not chosen randomly or haphazardly from a pool of sites but were selected using the criterion that they should contain the 3 habitat types in similar spatial configuration. The consequence of this choice for the interpretation of experimental results is that generalizations from this study should be considered with caution. Proportions were tested for homogeneity of variances with Cochran's test (at $\alpha=0.05$ ) and anqular transformation was performed when necessary. Post hoc comparisons of means were carried out with the Student-Newman-Keuls (SNK) procedure (at $\alpha=0.05$ ).

\section{RESULTS}

Patterns of clam survivorship among the 3 habitat types varied depending on whether field plots were enclosed with buried fences or left unfenced (habitat $x$ fencing interaction effect: $p=0.013$; Table 2). The percentage of clams recovered live was significantly greater in the intertidal sand flats than in the subtidal sand bottoms and intertidal salt marshes, with no significant difference between these 2 habitat types, when clams were deployed in fenced field plots (Table 3, and SNK test). In contrast, the percentage of live clams was significantly greater in the intertidal sand flats and the subtidal sand bottoms than in the salt marsh habitat, with no significant difference between the subtidal and the intertidal unvegetated habitats, within unfenced plots (Table 3, and SNK test). These patterns were not affected by site or tethering treatment (no significant interaction effects of habitat with site and/or tethering treatment; Table 2).

There was a significant interaction effect of fencing and tethering treatment on the proportions of live

Table 2. Mean square terms (MS), F-ratios and corresponding significance level $(" p<0.05 ; \cdots p<0.01 ; \cdots p<0.001)$ of 4 -way fixed-factor ANOVAs performed on the different categories of clams: Live: proportion of live clams; Dead undamaged: proportion of dead clams with undamaged shells; Crushed or chipped: proportion of dead clams with crushed or chipped valves; Filed or drilled: proportion of dead clams with filed or drilled valves; Missing: proportion of missing clams

\begin{tabular}{|c|c|c|c|c|c|c|c|c|c|c|c|}
\hline \multirow[t]{2}{*}{ Source } & \multirow[t]{2}{*}{ df } & \multicolumn{2}{|c|}{ Live } & \multicolumn{2}{|c|}{ Dead undamaged } & \multicolumn{2}{|c|}{ Crushed or chipped } & \multicolumn{2}{|c|}{ Filed or drilled } & \multicolumn{2}{|c|}{ Missing } \\
\hline & & MS & $F$ & MS & $F$ & MS & $\hat{F}$ & MS & $F$ & MS & $F$ \\
\hline Site (S) & 1 & 0.21 & $9.01^{\cdots}$ & 0.43 & $10.36^{*}$ & 0.06 & 1.25 & 0.02 & 1.47 & 0.003 & 0.25 \\
\hline Habitat (H) & 2 & 0.26 & $10.82 \cdots$ & 0.10 & 2.34 & 0.03 & 0.48 & 0.12 & $11.20 \cdots$ & 0.28 & $21.24^{\cdots}$ \\
\hline Fencing (F) & 1 & 0.15 & $6.21^{\circ}$ & 0.19 & $4.54^{\circ}$ & 0.002 & 0.03 & 0.003 & 0.29 & 0.04 & 3.34 \\
\hline Tethering (T) & 1 & 0.21 & $9.01 \cdots$ & 0.24 & $5.68^{\circ}$ & 0.11 & 2.20 & 0.01 & 1.06 & 0.65 & $49.58 \cdots$ \\
\hline $\mathrm{S} \times \mathrm{H}$ & 2 & 0.007 & 0.28 & 0.11 & 2.61 & 0.04 & 074 & 0.02 & 1.47 & 0.01 & 0.77 \\
\hline $\mathrm{S} \times \mathrm{F}$ & 1 & 0.09 & 3.61 & 0.01 & 0.34 & 0.13 & 2.56 & 0.005 & 0.43 & 0.001 & 0.05 \\
\hline $\mathrm{H} \times \mathrm{F}$ & 2 & 0.11 & $4.51^{\circ}$ & 0.002 & 0.05 & 0.04 & 0.72 & 0.003 & 0.29 & 0.03 & 2.09 \\
\hline $\mathrm{S} \times \mathrm{T}$ & 1 & 0.001 & 0.04 & 0.001 & 0.02 & 0.01 & 0.27 & 0.00 & 0.0004 & 0.006 & 0.44 \\
\hline $\mathrm{H} \times \mathrm{T}$ & 2 & 0.03 & 1.26 & 0.02 & 0.57 & 0.08 & 1.60 & 0.01 & 1.06 & 0.02 & 1.57 \\
\hline $\mathrm{F} \times \mathrm{T}$ & 1 & 0.11 & $4.52^{\circ}$ & 0.007 & 0.18 & 0.05 & 1.01 & 0.005 & 0.43 & 0.08 & $6.15^{\circ}$ \\
\hline $\mathrm{S} \times \mathrm{H} \times \mathrm{F}$ & 2 & 0.01 & 0.45 & 0.01 & 0.31 & 0.02 & 0.32 & 0.005 & 0.43 & 0.01 & 0.73 \\
\hline $\mathrm{S} \times \mathrm{H} \times \mathrm{T}$ & 2 & 0.04 & 1.68 & 0.02 & 0.44 & 0.04 & 0.83 & 0.00 & 0.0004 & 0.009 & 0.66 \\
\hline $\mathrm{S} \times \mathrm{F} \times \mathrm{T}$ & 1 & 0.03 & 1.15 & 0.10 & 2.27 & 0.01 & 0.16 & 0.03 & 2.77 & 0.001 & 0.06 \\
\hline $\mathrm{H} \times \mathrm{F} \times \mathrm{T}$ & 2 & 0.01 & 0.45 & 0.008 & 0.21 & 0.02 & 0.35 & 0.005 & 0.43 & 0.01 & 1.05 \\
\hline $\mathrm{S} \times \mathrm{H} \times \mathrm{F} \times \mathrm{T}$ & 2 & 0.003 & 0.14 & 0.05 & 1.18 & 0.14 & 2.68 & 0.03 & 2.77 & 0.005 & 0.36 \\
\hline Residual & 96 & 0.024 & & 0.042 & & 0.051 & & 0.011 & & 0.013 & \\
\hline
\end{tabular}


Table 3. Means ( $n=10$ ) and standard errors (in parentheses) for the different categories of clams in the 3 habitat types and the 4 treatment combinations. Percentages were pooled between the 2 sites because the effects of site did not significantly interact with the effects of the other factors for any of the variables (see Table 2). Clams recovered dead with undamaged shells had been killed by stress, disease or parasites. Clams with crushed or chipped valves had probably been consumed by crabs. Clams with valves filed at the edges or drilled had been consumed by whelks and moon snails, respectively. Missing clams may have been carried away by predators, have migrated from plots, passively transported by currents and waves, or might have been lost due to sampling error (see 'Methods')

\begin{tabular}{|c|c|c|c|c|}
\hline & \multicolumn{2}{|c|}{ Fenced plots } & \multicolumn{2}{|c|}{ Unfenced plots } \\
\hline & Tethered clams & Untethered clams & Tethered clams & Untethered clams \\
\hline \multicolumn{5}{|l|}{ Subtidal sand bottom } \\
\hline$\%$ live & $45.0(5.0\}$ & $47.0(5.6)$ & $58.0(4.7)$ & $42.0(5.3)$ \\
\hline$\%$ dead undamaged & $7.0(2.6)$ & $8.0(3.3)$ & $14.0(4.3)$ & $9.0(3.1)$ \\
\hline$\%$ crushed or chipped & $21.0(4.8)$ & $16.0(5.6)$ & $14.0(3.1)$ & $16.0(4.8)$ \\
\hline$\%$ filed or drilled & $5.0(4.0)$ & $5.0(3.1)$ & $1.0(1.0)$ & $4.0(1.6)$ \\
\hline$\%$ missing & $21.0(3.8)$ & $24.0(3.1)$ & $13.0(1.5)$ & $29.0(4.3)$ \\
\hline \multicolumn{5}{|l|}{ Intertidal sand flat } \\
\hline$\%$ live & $70.0(2.1)$ & $58.0(4.7)$ & $64.0(5.6)$ & $47.0(4.7)$ \\
\hline$\%$ dead undamaged & $13.0(2.6)$ & $8.0(2.9)$ & $18.0(2.9)$ & $13.0(3.3)$ \\
\hline$\%$ crushed or chipped & $14.0(2.2)$ & $14.0\{3.7\}$ & $11.0(3.8)$ & $16.0(4.8)$ \\
\hline$\%$ filed or drilled & 0 & 0 & 0 & 0 \\
\hline$\%$ missing & $3.0(1.5)$ & $19.0(3.8)$ & $6.0(2.7)$ & $24.0(4.3)$ \\
\hline \multicolumn{5}{|l|}{ Intertidal salt marsh } \\
\hline$\%$ live & $51.4(6.8)$ & $54.0(5.8)$ & $41.3(4.5)$ & $31.0(4.1)$ \\
\hline$\%$ dead undamaged & $11.2(3.5)$ & $5.0(2.2)$ & $14.1(3.4)$ & $9.0(3.8)$ \\
\hline$\%$ crushed or chipped & $19.2(4.8)$ & $11.0\{4.3\}$ & $24.3(4.3)$ & $13.0(3.0)$ \\
\hline$\%$ filed or drilled & 0 & 0 & 0 & 0 \\
\hline$\%$ missing & $20.4(4.2)$ & $30.0\{4.5\}$ & $21.3(3.3)$ & $47.0(3.7)$ \\
\hline
\end{tabular}

clams (Table 2). At both sites and in all habitats, significantly lower proportions of live clams were retrieved from the treatment where no prey restraints were used (untethered clams in unfenced plots) than in all other treatment combinations (Table 3 , and SNK test).

The percentages of clams recovered dead with undamaged shells were similar among the 3 habitat types (Tables $2 \& 3$ ). Fencing and tethering treatment had significant effects on proportions of dead undamaged clams, but these effects were similar among habitat types (no significant interaction effects; Table 2). Proportions of dead undamaged clams were significantly lower within fenced than within unfenced plots (Table 3, and SNK test). Significantly greater percentages of dead clams with undamaged shells were recovered when clams were tethered than untethered, suggesting that handling or stress associated with tethering caused greater clam mortality or that tethers prevented passive transport of dead shells out of the plots (Table 3, and SNK test).

Dead clams with marks attributed to predatory gastropods (shells drilled or filed at the edges) were recovered only in subtidal sand bottoms (Tables $2 \& 3$ ). In contrast, similar percentages of clams with predation marks attributed to crabs (shells crushed or chipped) were found in the 3 habitat types (Tables $2 \& 3$ ). None of the interaction terms of the 4 -way ANOVAs had significant effects on these categories of clam mortality (Table 2).
Most clam losses were due to missing clams (Table 3). Percentages of missing clams were significantly different among the 3 habitat types (Table 2). Salt marsh habitats had the greatest proportions of missing clams, whereas intertidal sand flats had the lowest. Subtidal sand bottoms had proportions of missing clams that were intermediate and significantly different from the other 2 habitats (Table 3 , and SNK test). There was a significant interaction between the effects of tethering and fencing treatments on the percentage of missing clams (Table 2). At both sites and in all 3 habitat types, the greatest proportions of missing clams were recorded from the treatment where no prey restraints were used (Table 3, and SNK test): The lowest proportions of missing clams were observed when clams had been tethered, with no significant difference between fenced and unfenced plots (Table 3 , and SNK test). Untethered clams deployed within fenced plots had proportions of missing clams that were intermediate between these 2 extremes, and significantly different from both (Table 3, and SNK test).

\section{DISCUSSION}

Studies conducted on exposed temperate rocky shores found a decrease in predation intensity with increased elevation on the shore and hypothesized that 
this result may be caused by a time limitation to foraging by marine predators high on the shore (Dayton 1971, Connell 1972, 1975, Menge 1978a, b, 1983; but see Underwood \& Denley 1984, Peterson 1991, for critical reviews). The hypothesis that clam survivorship is greater in intertidal than shallow-subtidal habitats, possibly because of a time limitation for marine predators in the intertidal habitats, was not consistently supported by this experiment. Results, in fact, varied depending on the type of experimental manipulation used to compare clam survivorship between subtidal and intertidal habitats. Significantly more clams were recovered live from intertidal sand flats than from subtidal sand bottoms when field plots had been enclosed with buried fences (Tables $2 \& 3$ ). In contrast, proportions of live clams were not significantly different between the subtidal sand bottoms and the intertidal sand flats in the unfenced treatments (Tables $2 \& 3$ ). In addition, results of experiments sinilar to the one reported here but replicated at more tidal elevations and at different times of the year conducted in a companion study found a decrease in predation intensity on tethered clams with increasing tidal elevation of sand flats in fall but not in summer (Micheli 1996). Seasonal variation in the composition of the predatory guilds and possibly in the behavior of individual predators (Micheli 1996) adds an additional source of variability to the effects of tidal elevation on clam survivorship. Seasonal variation in the composition or behavior of the predator assemblage may cause interaction effects of experimental artifacts and habitat to vary with the time of the year

In contrast to other marine soft-sediment systems, where seagrasses (Coen et al. 1981. Peterson 1982a, Summerson \& Peterson 1984, Leber 1985) and algal clumps (Herrnkind \& Butler 1986) have been shown to provide a refuge from predation for benthic prey, the presence of marsh vegetation enhanced loss of juvenile hard clams in this experiment. Regardless of the type of prey restraint used, clam survivorship was always significantly greater in unvegetated habitats (intertidal sand flats) than just inside the edge of vegetated habitats (intertidal salt marshes) of similar tidal elevation (Tables $2 \& 3$ ). Although the magnitude of the differences in survivorship between the 2 habitat types varied among treatment combinations (Table 3), these differences were not significant at $\alpha=0.05$. This experiment only examined the effects of predation near the edge of salt marshes but additional experiments have shown that survivorship of juvenile clams and oysters was not significantly different between approximately 1 and 15 to $20 \mathrm{~m}$ from the edges of salt marsh islands (F. Micheli unpubl. data). The greater predation intensity on juvenile bivalves in vegetated than in unvegetated intertidal habitats may be explained by the fact that the most common epibenthic predator in this system, the blue crab Callinectes sapidus, has greater feeding rates in intertidal salt marshes than in unvegetated flats of similar elevation (Micheli 1996). Structure, in the form of marsh plants, appears to protect blue crabs from their predators such as herring and ring-billed gulls (Larus argentatus Coues and $L$. delawarensis Ord; Prescott 1990, F Michelj pers, obs.). In addition, crabs encounter greater prey availability in the marsh habitat and thus aggregate in this habitat type (Micheli 1996). In this experiment, natural prey abundances in the field plots were not manipulated before adding the clams, and thus total prey abundances in the plots were likely to be greater in the salt marsh than in the unvegetated habitats. The effects of emergent aquatic vegetation on predation rates on clams may be large enough to mask the possible variation of predation estimates caused by experimental artifacts.

Based on the percentages of clams that were recovered dead with different types of predation marks on their shells, the composition of the predatory guild appeared to vary among the different habitat types Evidence of crab predation (crushed or chipped shells) was found in all habitat types (Table 3). In contrast, evidence of predation by gastropods (filed or drilled shells) was found only in the subtidal sand bottoms (Table 3). However, the possibility that the same type of predator modifies its foraging behavior in different habitats cannot be ruled out because it is not known what caused the missing clams. Therefore, it is not possible to determine whether the types or the behaviors of clam predators differed among the 3 habitat types based on these data. For example, marine predators foraging in intertidal habitats may carry their prey to lower tidal elevations before consumption, whereas they may consume prey in situ when foraging in subtidal habitats. Under this scenario, the same predator type would cause clams to be missing in the intertidal habitat yet to be retrieved as dead clams with predation marks in the subtidal habitat. Habitat-specific differences in a predator's foraging behavior may cause experimental artifacts of prey restraint to vary among habitats.

Tethers and fences had qualitatively similar effects on estimates of clam survivorship in each habitat type. Both types of restraint increased the percentages of live clams compared to the untethered-unfenced treatment, although the effects of fencing and tethering had different magnitudes (Table 3 ). This result contrasts with results of previous studies, where tethering generally enhanced prey mortality (Barbeau \& Scheibling 1994, Zimmer-Faust et al. 1994, Pile et al. 1996). In this experiment, prey restraints increased proportions of live clams by reducing the proportion of missing clams 
(Table 3). Tethers and fences may have decreased proportions of missing clams either by constraining movements of live clams and passive transport of both live and dead clams, or by interfering with a predator's ability to consume clams. These different effects of tethers and fences on prey losses cannot be teased apart in this experiment. Fences prevented clam migration but may also have affected predators foraging by adding structure to the plots. Tethers prevented clam migration and passive transport but may also have interfered with the predators' ability to carry away prey for consumption.

Previous studies have investigated habitat $x$ tethering interactions in the laboratory (Barshaw \& Able 1990, Pile et al. 1996). A limitation of laboratory tests of tethering $\times$ habitat interactions is that aquaria themselves constrain prey movements and limit escape responses of untethered prey. Unless the spatial scales of aquaria reflect the natural range of movement of prey (e.g. Smith 1995), laboratory tests are likely to introduce an additional, uncontrolled bias in relative comparisons of predation intensity between different habitat types. Few field studies have shown that experimental artifacts can interact with treatment in ecological field experiments. Smith (1995) provided evidence of a significant tethering $\times$ treatment interaction in the effect of limb loss of juvenile blue crabs on their susceptibility to cannibalism in the field. In large field enclosures, adult blue crabs consumed similar proportions of untethered juvenile crabs assigned to $4 \mathrm{limb}$ loss treatments (e.g. missing 0, 1 or 4 limbs), while significant differences in predation intensity were found among the different limb loss treatments when juvenile crabs were tethered. Artifacts associated with another type of experimental manipulation, the use of settlement plates, have also been shown to differ among treatments (Kennelly 1983).

Direct estimates of the proportions of clams last to different predator types and of the modifications of predatory behavior induced by tethering and fencing in the different habitats are not possible in this experiment because it is not known why the clams were missing. The magnitude of the effects of these prey restraints on the proportions of missing clams varied among habitats (Table 3), although not significantly so (Table 2), indicating that either the rates of clam migration/passive transport or the effects of the prey restraints on predator behavior may have differed slightly among habitats. Both scenarios are likely to occur because physical and biological factors that affect prey movements, prey passive transport and predator behavior, such as sediment characteristics, habitat structural complexity, water current velocities, intra-and interspecific competition, and risk of predation from higher-order predators, vary among habitats.
The actual mechanisms underlying differences in prey losses among habitats can only be identified with direct behavioral observations of predator-prey interactions. Direct observations of predator-prey interactions using underwater video (Barbeau \& Scheibling 1994) and time-lapse photography seem the most appropriate approach for this task because these techniques reduce the probability of influencing the behavior of predators (e.g. Aronson \& Heck 1995) and permit the measurement of predation rates in the field.

In conclusion, this study provides evidence that experimental artifacts can bias comparisons of relative predation intensity among soft-sediment marine habitats (Peterson \& Black 1994, but see Aronson \& Heck 1995 for a critique). Experimental manipulations have proved to be invaluable tools for understanding factors and processes that structure natural communities. An awareness of the potential bias generated by artifact. $x$ treatment interactions does not decrease the value of manipulative field experiments in ecology, but it does increase the care needed in interpreting experimental results.

Acknowledgements. I thank C. H. Peterson for pointing out the potential for tethering $\times$ habitat interactions in my experiments, G. A. Skilleter for helping me with the experimental design and data analyses, and J. Huber (ARC Inc., Atlantıc, $\checkmark C$ ) for providing the clams used in this experiment. I also thank A. R. Hall and B. A. Orlando for helping with field work, and R. N. Lipcius and A. J. Pile for promptly providing information about their work. R. Bolser, M. Deal, M. E. Hay, R. Karlson, H. S. Lenihan, M. Nakaoka, C. H. Peterson, G. A. Skilleter, T G. Wolcott and 4 anonymous reviewers improved the manuscript. Financial support for this study was provided by a grant from the State Legislature of North Carolina (through the Division of Marıne Fisheries) to C. H. Peterson, a Fulbright scholarship for graduate studies in the United States to F.M., and a dissertation fellowship of the graduate school of UNC-CH to F.M. This research was done in partial fulfillment of the requirements for a PhD degree at the University of North Carolina at Chapel Hill

\section{LITERATURE CITED}

Ambrose WG Jr (1984) Influenccs of predatory polychaetes and epibenthic predators on the structure of a soft-bottom community in a Mane estuary. J Exp Mar Biol Ecol 81: $115-145$

Arnold WS (1984) The effects of proy size, predator size, and sediment composition on the rute of predation of the blue crab, Callinectes sapidus Rathbun, on the hard clam, Mercenaria mercenaria (Linne). J Exp Mar Bıol Ecol 80: $207-219$

Aronson RB, Heck KL Jr (1995) Tethering experiments and hypothesis testing in ecology. Mar Ecol Prog Ser 121: 307-309

Barbeau MA, Scherbling RE (1994) Procedural effects and the analysis of prey tothering experiments: predation of Juvenile scallops by crabs and seastars. Mar Ecol Prog Ser 111. $305-310$

Barshaw DE, Able KW (1990) Tethering as a technique for assessing predation rates in different habitats: an evalua- 
tion using juvenile lobsters, Homarus americanus. Fish Bull 88:415-417

Bennington CC, Thayne WV (1994) Use and misuse of mixed model analysis of variance in ecological studies. Ecology 75:717-722

Coen LD, Heck KL, Abele LE (1981) Experiments on competition and predation among shrmps of seagrass meadows. Ecology 62:1484-1493

Commito JA (1982) The importance of predation by infaunal polychaetes in controlling the structure of a soft-boltom community in Maine USA. Mar Biol 68:77-81

Connell JH (1972) Community interactions on marine rocky intertidal shores. A Rev Ecol Syst 3:169-192

Connell JH (1975) Some mechanisms producing structure in natural communitıes: a model and some evidence from field experiments. In: Cody ML, Diamond JM (eds) Ecology and evolution of communities. Belknap Press, Cambridge, $\mathrm{p} 460-490$

Dayton PK (1971) Competition, disturbance and community organization: the provision and subsequent utilization of space in a rocky intertidal community. Ecol Monogr 41:351-389

Folk RL (1980) Petrology of sedimentary rocks, 2nd edn. Hemphill, Austin

Heck KL Jr, Thoman TA (1981) Experiments on predator-prey interactions in vegetated aquatic habitats. J Exp Mar Biol Ecol 53:125-134

Herrnkind WF, Butler MJ IV (1986) Factors regulating postlarval settlement and juvenile microhabitat use by spiny lobsters Palinurus argus. Mar Ecol Prog Ser 34:23-30

Irlandi EA, Peterson CH (1991) Modification of animal habitat by large plants: mechanisms by which seagrasses influence clam growth. Oecologia 87:307-318

Kennelly SJ (1983) An experimental approach to the study of factors affecting algal colonization in a sublittoral kelp forest. J Exp Mar Biol Ecol 68:257-276

Kneib RT (1984) Patterns of invertebrate distribution and abundance in the intertidal saltmarsh: causes and questions. Estuaries 7:392-412

Leber KM (1985) The influence of predatory decapods, refuge, and microhabitat selection on seagrass communities. Ecology 66:1951-1964

Lima SL, Dill LM (1990) Behavioral decisions made under the risk of predatıon: a review and prospectus. Can J Zool 68: $619-640$

Lipcius RN, Hines AH (1986) Variable functional responses of a marine predator in dissimilar homogeneous microhabitats. Ecology 67:1361-1371

MacKenzie CL Jr (1977) Predatıon on the hard clam Mercenana mercenaria populations. Trans Am Fish Soc 106:530-537

Menge BA (1978a) Predation intensity in a rocky intertidal community. Relation between predator foraging activity and environmental harshness. Oecologia 34:1-16

Menge BA (1978b) Predation intensity in a rocky intertidal community. Effect of algal canopy, wave action and desiccation on predator feeding rates. Oecologia 34:17-35

Menge BA (1983) Components of predation intensity in the low zone of a New England rocky intertidal region. Oecologia 58:141-155

Menge BA, Lubchenco J (1981) Communty organizatıon in temperate and tropical rocky intertidal habitats: prey refuges in relation to consumer pressure gradients. Ecol Monogr 51:429-450

Micheli F (1996) Prey-patch and habitat use by blue crabs effects of predator foraging behavior on patterns of prey mortality in marine soft boltoms. Ecology (in press)

This article was presented by R. H. Karlson (Senior Editorial Advisor), Newark, Delaware, USA
Paine RT (1966) Food web complexity and species diversity. Am Nat 100:65-75

Peterson CH (1982a) Clam predation by whelks (Busycon spp.): experimental tests of the importance of prey size, prey density, and seagrass cover. Mar Biol 66:159-170

Peterson CH (1982b) The importance of predation and intraand interspecific competition in the population biology of two infaunal suspension-feeding bivalves, Protothaca stamined and Chione undatella. Ecol Monogr 52:437-475

Peterson CH (1990) On the role of ecological experimentation in resource management: managing fisheries through mechanistic understanding of predator feeding behaviour. In: Hughes RN (ed) Behavioural mechanısms of food selection. NATO ASI Series, Vol G 20. Springer-Verlag, Berlin, p $821-846$

Peterson CH (1991) Intertidal zonation of manne invertebrates in sand and mud. Am Sci 79:236-249

Peterson CH, Beal BF (1989) Bivalve growth and higher order interactions: importance of density, site, and time. Ecology 70:1390-1404

Peterson CH, Black R (1993) Experimental tests of the advantages and disadvantages of high density for two coexisting cockles in a Southern (Jrean lagoon J Anim Ecol 62: $614-633$

Peterson CH, Black R (1994) An experımentalist's challenge: when artifacts of intervention interact with treatments Mar Ecol Prog Ser 111:289-297

Peterson $\mathrm{CH}$, Summerson HC, Duncan PB (1984) The influence of seagrass cover on population structure and individual growth rate of a suspension-feeding bivalve, Mercenaria mercenaria. J Mar Res 42:123-138

Pile AJ, Lipcius RN, Van Montfrans J, Orth RJ (1996) Densitydependent settler-recruit-juvenile relationships in blue crabs. Ecol Monogr 66:277-300

Prescott RC (1990) Sources of predatory mortality in the bay scallop Argopecten irradians (Lamarck): interactions with seagrass and epibiotic coverage. J Exp Mar Biol Ecol 1.44: $63-83$

Reise K (1985) Tidal flat ecology. Springer-Verlag, Berlin

Sih A, Crowley P, McPeek M, Petranka J, Strohmeier K (1985) Predation, competition, and prey communities: a review of field experiments. A Rev Ecol Syst 16:269-311

Smith LD (1995) Effects of limb autotomy and tethering on juvenile blue crab survival from cannibalism. Mar Ecol Prog Ser 116:65-74

Summerson HC, Peterson $\mathrm{CH}$ (1984) Role of predation in organizing benthic communities of a temperate-zone seagrass bed. Mar Ecol Prog Ser 15:63-77

Underwood AJ, Denley EJ (1984) Paradigms, explanations and generalizations in models for the structure of intertidal communities on rocky shores. In: Strong DR, Simberloff DS, Abele LG, Thistle AB (eds) Ecological communities: conceptual issues and the evidence. Prnceton University Press, Princeton, NJ, p 151-180

Whetstone JM, Eversole AG (1981) Effects of size and temperature on mud crab, Panopeus herbstii, predation on clams, Mercenaria mercenaria. Estuarıes 4:153-156

Wilson RH Jr (1990) Competition and predation in marine soft-sediment communities. A. Rev Ecol Syst 21:221-241

Wootton JT (1993) Indirect effects and habitat use in an untertidal community: interaction chains and interaction modifications. Am Nat 141:71-89

Zimmer-Faust RK, Fielder DR, Heck KL Jr, Coen LD, Morgan SG (1994) Effects of tethering on predatory escape by juvenile blue crabs. Mar Ecol Prog Ser 111:299-303

Manuscnpt first received: February 6,1995

Revised version accepted: May 28, 1996 